\title{
Features of di George syndrome in a child with $45, \mathrm{XX},-3,-22,+\operatorname{der}(3), \mathrm{t}(3 ; 22)(\mathrm{p} 25 ; \mathrm{q} 11)$
}

\author{
M J W FAED*, J ROBERTSON*, J SWANSON BECK†, \\ J I CATER , B BOSE $\ddagger$, AND M M MADLOM
}

*Cytogenetics Laboratory, †Immunology Laboratory, Department of Pathology, and $\ddagger$ Department of Child Health, University of Dundee, Dundee DD1 9SY.

SUMMARY A child with an unbalanced translocation resulting in monosomy for chromosomes 22 ( $111 \rightarrow$ pter) and $3(\mathrm{p} 25 \rightarrow$ pter $)$ is described. Although no immunological dysfunction could be demonstrated, the abnormalities found are similar to those seen in the di George syndrome which has been associated with monosomy for the same region of chromosome 22 .

The clinical features of di George syndrome (DGS) include neonatal hypocalcaemia, defective cellular immunity, absent parathyroid and thymus glands, atypical facial features, and cardiovascular anomalies. ${ }^{12}$ More recent reports ${ }^{3}$ suggest a greater variability of the syndrome than originally described and Lischner ${ }^{4}$ advocated the name partial DGS to include these patients, some of whom have small amounts of thymic tissue and little, if any, immunological deficiency. There is evidence for an association of a partial deletion of chromosome 22 and DGS. ${ }^{5-7}$ We report here a child with an unbalanced chromosome translocation $(3 ; 22)$ with some features of DGS.

\section{Case report}

The child was the second daughter of nonconsanguineous Asian parents. There is no family history of illness. The pregnancy was complicated by a urinary tract infection at five weeks and bleeding due to placenta praevia at 36 weeks. Fetal growth slowed considerably during the last part of pregnancy to such an extent that a Caesarian section was carried out at 37 weeks. Marked meconium staining was noted and respirations were established at five minutes. Her birth weight was $2120 \mathrm{~g}$ (<10th

Received for publication 15 October 1985.

Accepted for publication 24 October 1985. centile), occipitofrontal circumference $29.5 \mathrm{~cm}$ ( $<10$ th centile), and length $47 \cdot 2 \mathrm{~cm}$ ( 25 th centile). A number of dysmorphic features were noted soon after birth and included broad thumbs, upward slanting eyes, micrognathia, fish-like shape of mouth, short philtrum, and low set ears. A soft grade $4 / 6$ pansystolic murmur was also heard. Tachypnoea caused feeding difficulties and prolonged her stay in hospital. Feeding caused significant difficulty throughout infancy requiring gavage feeding. Her weight gain was initially slow but by six months was on the 10th centile, although her head circumference continued to increase at a constant rate below the 10 th centile.

\section{INVESTIGATIONS}

Chest $x$ ray during the neonatal period, and tomography later, failed to show a thymic shadow. The values for serum calcium $(2.56 \mathrm{mmol} / \mathrm{l})$ and phosphate $(1.84 \mathrm{mmol} / \mathrm{l})$ were normal. Urea was $2.5 \mathrm{mmol} / \mathrm{l}$. and creatinine $37 \mathrm{mmol} / \mathrm{l}$. IgG $(4.7 \mathrm{~g} / \mathrm{l})$ and $\operatorname{IgA}$ $(0.31 \mathrm{~g} / \mathrm{l}$, assessed at 13 weeks, were within the normal range for age although IgM $(1.27 \mathrm{~g} / \mathrm{l})$ was raised. Lymphocytes showed a normal response to in vitro stimulation with phytohaemagglutinin, concanavalin $\mathbf{A}$, or pokeweed mitogen and no abnormality was detected in the proportion of lymphocytes identified by T3, T4, T8, B, or M markers. Phagocytosis of ${ }^{131}$ I labelled zymogen particles by polymorphonuclear cells was normal. Rubella HAI titre was less than 8 and CMV IgG antibody titre (FA) was less than 64 . Cardiac catheterisation showed a small VSD and subsequent angiography demonstrated a complete absence of the left pulmonary artery.

\section{CYTOGENETIC STUDIES}

Chromosome preparations of lymphocytes and fibro-

blasts revealed an unbalanced translocation between 


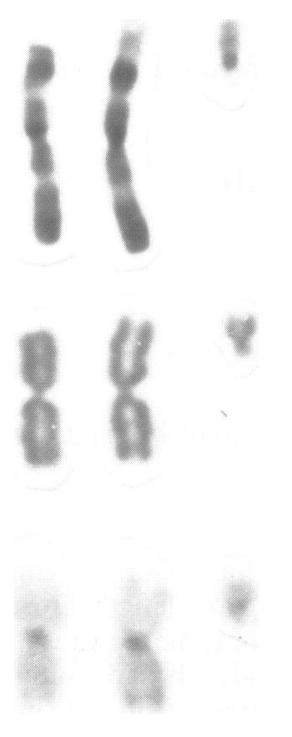

FIGURE Partial karyotypes illustrating (from left to right) the normal chromosome 3 , the derivative 3 , and chromosome 22 stained by trypsin-Giemsa (top), orcein (middle), and C banding (bottom).

chromosomes 3 and 22 (figure). The breakpoint on chromosome 3 was at $\mathrm{p} 25$. There was no evidence of a second centromere either by orcein, trypsinGiemsa, or $\mathrm{C}$ band staining of the derivative chromosome, suggesting that the breakpoint on chromosome 22 was in band $\mathrm{q} 11$ resulting in a deletion of $3 p 25 \rightarrow$ pter and $22 q 11 \rightarrow$ pter. No chromosome abnormality was detectable in either of the clinically normal parents or the sister of the proband.

\section{Discussion}

This child, investigated because of dysmorphic features noted in the neonatal period, was found to have an unbalanced chromosome translocation involving loss of material from both chromosomes 3 and 22.

Children with congenital abnormality and unbalanced inversion products resulting from familial pericentric inversions of chromosome 3 with a breakpoint at p25 have been reported, ${ }^{8}$ but recognition of features specifically due to p25 $\rightarrow$ pter deletion is difficult in these cases. A child with an unbalanced translocation resulting in partial trisomy 17 and deletion of 3 p $25 \rightarrow$ pter showed phenotypic abnormalities characteristic of trisomy $17 .{ }^{9}$ Pure monosomy for 3 p25 has been reported in four cases $\stackrel{\overparen{\Phi}}{\rightarrow}$ (reviewed in Higginbottom et $a l^{10}$ ) and these show $\overrightarrow{\vec{F}}$ similar congenital abnormalities, but of an unspecific $\stackrel{\rho}{?}$ nature.

De la Chapelle $e t$ al ${ }^{5}$ reported a child with the di George syndrome in association with an unbalanced $\frac{\sigma}{\sigma}$ translocation between chromosomes 20 and 22 . The $\propto$ balanced form of the translocation was found to be familial and three earlier children had died with $\vec{\circ}$ similar symptoms. The suggestion that the di George syndrome is associated with deletion of $22 q 11 \rightarrow$ pter $\vec{\omega}$ was supported by reports from Kelley et at and $\stackrel{S}{S}$ Greenberg et $\mathrm{al}^{7}$ of four unrelated cases of patients with a di George-like phenotype, a variable degree of i clinical expression, and an unbalanced translocation $\stackrel{f}{+}$ involving chromosome 22 with chromosomes $3,4, \dot{\sim}$ 10 , or 20 . The mother of the child with the $4 ; 22 \mathrm{~N}$ translocation also carried the unbalanced trans-o location, but was asymptomatic although investigation showed her to have a partial $\mathrm{T}$ cell deficiency. Thus, even within one family, there is a marked variation in clinical expression.

There is some difficulty in establishing the exact $\bar{\oplus}$ breakpoint of these translocations involving the. pericentric region of chromosome 22. De la Chapelle et $a l^{5}$ have argued that the absence of any evidence of di George type symptoms in patients with $21 ; 22$ 응 translocations or $22 p$ deletion would suggest that the deletion of significance is at $\mathrm{q} 11$ and not on the short $\stackrel{\unrhd}{\stackrel{2}{2}}$ arm. In our patient, there is no evidence of a second $\overrightarrow{\vec{\theta}}$ centromere on the derivative chromosome but it $\frac{0}{3}$ would appear that most, if not all, of $22 q$ is present, implying a breakpoint at q11.

The clinical features of this child, which are shared with those of patients with DGS, include upwardo slanting eyes, short philtrum, fish-like mouth, micro- $\dot{0}$ gnathia, low set ears, an absent left pulmonary artery, and ventricular septal defect. Our patient lacks the classical features of hypoparathyroidism and defec- $₹$ tive cellular immunity described by di George' 을 although no thymus was visible on $x$ ray and she has facial features and cardiac anomalies consistent with을 the partial DGS. ${ }^{4}$

Although the specific breakpoint may be impor- or tant in some cases the variation in the clinical $N$ features in cases with similar deletions may say more $\mathrm{N}_{\mathrm{W}}$ about the activity of the alleles for which the patient 0 is effectively hemizygous than about those that are missing.

\section{References}

' Di George AM. Discussion following Cooper MD, Peterson RDA, Good RA. New concept of cellular basis of immunity. $J \mathbb{\Phi}$ Pediatr 1965;67:907-8.

2 Freedom RM, Rosen FS, Nadas AS. Congenital cardiovascular 
disease and anomalies of the third and fourth pharyngeal pouch. Circulation 1972;46:165-72.

3 Conley ME, Beckwith JB, Mancer JFK, Tenckhoff L. The spectrum of the di George syndrome. J Pediatr 1979;94:883-90.

4 Lischner HW. Di George syndrome(s). J Pediatr 1972;81:1042-4.

5 de la Chapelle A, Herva R, Koivisto M, Aula P. A deletion in chromosome 22 can cause di George syndrome. Hum Genet 1981;57:253-6.

6 Kelley RI, Zackai EH, Emanuel BS, Kistenmacher M, Greenberg F, Punnett HH. The association of di George anomalad with partial monosomy of chromosome 22. $J$ Pediatr 1982;101:197-200.

7 Greenberg F, Crowder WE, Paschall V, Colon-Linares J, Lubianski B, Ledbetter DH. Familial di George syndrome and associated partial monosomy of chromosomes 22. Hum Genet 1984;65:317-9.

8 Allderdice PW, Browne N, Murphy DP. Chromosome 3 dupli- cation $\mathrm{q} 21 \rightarrow \mathrm{qter}$ deletion $\mathrm{p} 25 \rightarrow$ pter syndrome in children of carriers of a pericentric inversion inv(3)(p25q21). Am J Hum Genet 1975;27:699-718.

9 Shawe DJ, Fear C, Appleyard WJ. A child with partial trisomy of chromosome 17 and partial monosomy of chromosome 3: 46,XY,der(3),t(3;17)(p25;q23). J Med Genet 1983;20:383-5.

${ }^{10}$ Higginbottom MC, Mascarello JT, Hassin H, McCord WK. A second patient with partial deletion of the short arm of chromosome 3: karyotype 46,XY, der(3)(p25). J Med Genet 1982;19:71-3.

Correspondence and requests for reprints to $\mathrm{Dr}$ M J W Faed, Cytogenetics Laboratory, Department of Pathology, Ninewells Hospital and Medical School, Dundee DD1 9SY.

\title{
A child with partial monosomy $6 \mathrm{q}$ secondary to a maternal direct insertional event
}

\author{
S V MATKINS*, J E MEYER $\dagger$, AND A C BERRY* \\ ${ }^{*} S E$ Thames Regional Genetics Centre, Guy's Hospital, London SE1 9RT; and +Pembury Hospital, \\ Pembury, Tunbridge Wells, Kent TN2 4QJ.
}

SUMMARY We report a child, now aged two years, who is monosomic for the region $6 \mathrm{q} 23 \cdot 1 \rightarrow \mathrm{q} 24 \cdot 2$. Her mother, older sister, and twin sister have a balanced chromosome complement with this region of $6 q$ being inserted into 11q.

\section{Case report}

The proband was one of twins born to healthy nonconsanguineous parents; the mother was aged 35 and father 38 . The twins were born at term with the proband weighing $2.6 \mathrm{~kg}$ and her sister $3.1 \mathrm{~kg}$.

The mother had had two previous pregnancies. The first resulted in a healthy daughter and the second in a son who died aged six weeks from cardiac failure. He was reported as being dysmorphic with micrognathia and a large neck and unfortunately was not karyotyped. Necropsy (Dr R I K Elliott) showed cardiomegaly with a patent ductus arteriosus and a small patent foramen ovale but no explanation for the cardiomegaly. The skin was unusually thick and indurated.

There were no neonatal problems but the proband was slower to gain weight than her healthy sister. At

Received for publication 20 November 1985. Accepted for publication 29 November 1985. the age of five months she had the first of several hospital admissions for recurrent chest infections, persistent collapse of the right upper lobe, and failure to thrive. At the age of two years it was noted that length, weight, and head circumference growth rates had all fallen and the liability to infections persisted. She was globally delayed and barely able to sit unsupported. She transferred objects from hand to hand but said no meaningful words.

Her face was slightly dysmorphic (fig 1) with hypertelorism, prominent bridge to the nose, tented nares, and a small mouth with narrow upper lip. Overall her facies was reminiscent of that seen in the Wolf-Hirschhorn syndrome. Her palate was normal, her ears were low set, and her neck short, but no other abnormalities were noted.

Investigations have shown recurrent iron deficiency anaemia but normal immune function and sweat tests.

\section{CYTOGENETIC FINDINGS}

Peripheral blood lymphocytes from the proband, her twin sister, and both parents were cultured for chromosome studies with trypsin $\mathrm{G}$ banding. The proband showed a small interstitial deletion of the long arm of chromosome 6. Examination of the maternal chromosomes showed a direct insertional event between chromosome 6 and the long arm of 